\author{
Rafis Abazov \\ MDP Programme at Earth Institute at Columbia University, USA, New York \\ e-mail:r.abazov@yahoo.com
}

\title{
DIGITAL TRANSFORMATION OF IR AND UN STUDIES: CASE STUDY ON YOUTH ENGAGEMENT IN MODEL UN NEW SILK WAY
}

The quality of teaching international relations (IR) and UN studies depends on many factors, including the anchorage and localization of educational materials through practical exercises and extracurricular activities. In this regard, Model United Nations (Model UN) programs have proven to be one of the most effective activities, inculcating youth with necessary practical skills and competencies, especially soft skills in negotiating, debating, consensus seeking, and gender and multicultural sensitivity. However, over the past few years Model UN programs have been facing challenges in developing and expanding their engagement with young people due to the need to adapt the programs to new realities including the internationalization of higher education institutions (HEIs) and the COVID-19 restrictions and closures. A key tool in introducing necessary changes and responses to the challenges is digital transformation through the incorporation of information communication technologies (ICT), digital online learning (DOL), social media, and enhancing essential digital skills.

The purpose of this article is to analyze how digital transformation impacts teaching IR and UN studies in general, and implementing Model UN programs in particular. First, it introduces the framework of this research project. Second, it discusses the educational context of developing IR and UN studies and the recent growth and expansion of Model UN programs. Third, it provides a short literature review on the empirical and theoretical aspects of digital transformation. Fourth, it presents the case study of the impact of digital transformation especially of the use of ICT on the Model UN New Silk Way over the past 10 years. The conclusion summarizes the findings of this research and discusses some implications for educational process and practices in IR and UN studies, and for the internationalization of higher education.

Key words: Digital transformation, digital online learning, globalization, international relations, Model UN, UN studies, internationalization of education.

\section{Рафис Абазов}

MDP программасы, Колумбия университетіндегі Жер институты, АҚШ, Нью-Йорк к. e-mail: r.abazov@yahoo.com

ХҚ және БҰҰ оқытудағы цифрлық трансформация: жастарды БҰҰ-ның «Жаңа жібек жолы» моделіне тарту үлгісі

Халықаралық қатынастарды (ХҚ) және БҰҰ-ны оқыту сапасы көптеген факторларға, соның ішінде практикалық жаттығулар мен сыныптан тыс іс-шаралар арқылы оқу материалдарын бекіту мен оқшаулауға байланысты.

Осыған байланысты «Біріккен Ұлттар Ұйымының моделі» («БҰҰ Моделі») бағдарламалары жастарға қажетті практикалық дағдылар мен құзыреттерді, әсіресе келіссөздер, пікірсайыстар жүргізудің, консенсус іздеудің, гендерлік және көп мәдениетті сезімталдықтың жұмсак Аағдыларын дарытатын неғұрлым тиімді қызмет түрлерінің бірі болып шықты. Алайда, соңғы бірнеше жылда БҰҰ Модельдік бағдарламалары БҰҰ моделін жаңа шындыққа бейімдеу қажеттілігіне, оның ішінде жоғары оқу орындарының (ЖОО) интернационализациясы мен COVID-19-ға байланысты шектеулерге байланысты жастармен өзара іс-қимылды дамыту мен кеңейтуде проблемаларға тап болды.

Қажетті өзгерістер енгізу мен сын-тегеуріндерге жауап берудің маңызды құралдарының бірі АКТ енгізу арқылы цифрлық трансформация, цифрлық онлайн оқыту (DOL), әлеуметтік желілерді дамыту және маңызды цифрлық дағдыларды дамыту болып табылады.

Бұл мақаланың мақсаты - цифрлық трансформацияның халықаралық қатынастар мен БҰҰ-ны оқытуға және «БҰҰ Моделі» бағдарламаларын іске асыруға қалай әсер ететінін та^дау. Біріншіден, ол осы ғылыми жобаның тұжырымдамалық негізімен таныстырады. Екіншіден, ол Қорғаныс министрлігі мен БҰҰ зерттеулерін дамытудың білім беру мәнмәтінін, сондай-ақ Model UN бағларламаларының жақында өсуі мен кеңеюін талқылайды. Үшіншіден, ол сандық түрлендірудің эмпирикалық және теориялық аспектілері туралы әдебиеттерге қысқаша шолу 
жасайды. Төртіншіден, цифрлық трансформацияның БҰҰ-ның «Жаңа жібек жолы» моделіне соңғы 10 жылдағы (2012 жылдан 2021 жылға дейін) әсерін кейстік зерттеу ұсынылады. Қорытындыла осы зерттеудің нәтижелері жинақталады және білім беру мен БҰҰ зерттеулеріндегі білім беру процесі мен практикасы, сондай-ақ жоғары білімнің интернационализациясының кейбір мәселелері талқыланады.

Түйін сөздер: цифрлық трансформация, цифррлық онлайн оқыту, жаһандану, халықаралық, қатынастар, БҰҰ моделі, БҰҰ зерттеулері, білім беруді интернационалдандыру.

Рафис Абазов

Программа MDP, Институт Земли при Колумбийском университете, США, г. Нью-Йорк e-mail: r.abazov@yahoo.com

\section{Цифровая трансформация в преподавании МО и ООН: на примере вовлечения молодежи в модель ООН «Новый Шелковый путь»}

Качество преподавания международных отношений (МО) и модели ООН зависит от многих факторов, вк^ючая закрепление и локализацию учебных материалов посредством практических упражнений и внеклассных мероприятий. В этом отношении программы «Модель Организации Объединенных Наций» («Модель ООН») оказались одним из наиболее эффрективных видов Аеятельности, который прививает молодежи необходимые практические навыки и компетенции, особенно мягкие навыки ведения переговоров, Аебатов, поиска консенсуса, гендерной и многокультурной чувствительности. ОАнако за последние несколько лет программы Модели ООН столкнулись С проблемами в развитии и расширении взаимодействия с молодыми АюАьми из-за необходимости адаптации Модели ООН к новым реалиям, вк^ючая интернационализацию высших учебных заведений (ВУЗов) и ограничения, связанные с COVID-19. ОАним из важных инструментов внесения необходимых изменений и ответов на вызовы является цифровая трансформация через внедрение ИКТ, цифрового онлайн-обучения (DOL), социальных сетей и развития цифровых навыков. Цель данной статьи - проанализировать, как цифровая трансформация влияет на преподавание международных отношений и ООН в целом, и на реализацию программ «Модель ООН» в частности. Во-первых, Аанный проект знакомит с концептуальными рамками данного исследования. Во-вторых, в немобсуждается образовательный контекст развития исслеАований $\mathrm{MO}$ и ООН, а также неАавний рост и расширение программ Model UN. B-третьих, Аается краткий обзор митературы по эмпирическим и теоретическим аспектам цифровой трансформации. В-четвертых, представляет кейсовое исследование влияния цифровой трансформации на Модель ООН «Новый Шелковый путь» за последние 10 лет (с 2012 по 2021 гоА). В закАючение суммируются результаты этого исследования и обсуждаются некоторые последствия Аля образовательного процесса и практики в исследованиях МО и ООН, а также интернационализации высшего образования.

Ключевые слова: цифровая трансформация, цифровое онлайн-обучение, глобализация, международные отношения, модель ООН, исследования ООН, интернационализация образования.

\section{Introduction}

The concept of information society has moved from textbooks and intellectual discussions to everyday life, becoming a reality for many countries around the world. Contemporary trends in globalization and technological changes of the fourth industrial revolution are making the modern world increasingly complex. Scholars now argue that "the world is flat" (Friedman, 2007) as information and new communication tools become increasingly accessible to communities everywhere. In this context, the new technologies - especially digital technologies - impact "connectivity" within and between societies (van Dijck, 2013), where digital transformation could become part of effective solutions for many old challenges - or a new problem in itself. Thus, the use of ICT and other digital technologies in the preparation of qualified personnel for the area of international relations (IR) and United Nations Studies (UN studies) is a very important part of educating and mobilizing youth to deal with local and global challenges, from the implementation of Sustainable Development Goals (SDGs) and the fight against climate change, to conflict mitigation and resolution (in places like Afghanistan), to dealing with a whole range of economic and social aspects of globalization.

Over the past decade, higher education institutions (HEIs) and technical vocational education and training (TVET) colleges have undergone significant changes. The experience 
of many universities suggests that effective crossborder university collaboration and networking for enhancing IR and UN studies in today's complex world requires new approaches in teaching communicating these subjects, especially when it comes to developing practical experiences and expertise (Chapman, Pekol, \& Wilson, 2014).

In this context, the practical work of the Model UN programs around the world could be seen as an interesting and constructive approach to promoting practical skills among youth, and particularly students. However, the experience of organizing Model UN conferences and trainings suggests that over the past decade these programs have undergone some significant changes. These changes relate both to the search for tools to mobilize youth towards Model UN activities and the search for innovative approaches in organizing work with youth, implementing information campaigns and coordinating activities of universities through the United Nations Academic Impact program (Cheng, Angel Oi Yee, 2019). Model UN programs have been facing challenges in developing and expanding their engagement with young people given the need to adapt to new realities including the internationalization of HEIs, the digitalization of educational processes, and COVID-19-related closures and restrictions. An important tool in introducing necessary changes in response to these challenges has been digital transformation through the incorporation of information communication technologies (ICTs), e-learning (digital online learning (DOL)), social media, and essential digital skills.

The study of digital transformation of education in general and IR and UN studies in particular raises a variety of issues. The goal of this paper to address a number of related research questions as follows: How can we conceptualize the impact of digital transformation on education and youth mobilization? How did the concept of digital transformation in education evolve over time and how has it influenced thinking about modern educational processes? How is digital transformation impacting activities such as Model UN programs? This paper attempts to answer these and other questions using as an example the Model UN New Silk Way in Kazakhstan. In order to address the research questions the paper is organized as follows: First, it introduces the framework of this research project. Second, it discusses the educational context of developing IR and UN studies and the recent growth and expansion of Model UN programs. Third, it provides a short literature review on the empirical and theoretical aspects of digital transformation. Fourth, it presents the case study of the impact of digital transformation on the Model UN New Silk Way over the past 10 years (between 2011 and 2021). The conclusion summarizes the findings of this research and discusses some implications for educational process and practices in IR and UN studies, and for the internationalization of higher education.

\section{Research purpose}

The purpose of this article is to analyze how digital transformation has been changing the teaching of IR and UN studies in general and the implementation of Model UN programs in particular. This includes analysis of both the local and regional educational context and Model UN activities as a tool for developing the internationalization of student and youth education about the foundations of globalization. The article also assesses the dynamics of engagement and communication between student youth and educators on the use of traditional tools in the educational process, as well as the growing use of ICT in education, including teaching youth about the principles of UN and the work of the Model UN. In addition, it assesses the impact of the process of digital transformation on Model UN activities using the example of the Model UN New Silk Way program in Kazakhstan, which concentrated its work at three levels: city (Almaty), country (Kazakhstan), and region (greater Central Asia including Afghanistan).

\section{Importance of the study}

The importance of this study derives from the need to analyze both traditional and new mechanisms of the interactions of educational institutions with youth in promoting better knowledge of the UN system, SDGs, and the theory and practice of IR and UN studies (Hudzik, 2014). Because globalization, technical progress of the fourth industrial revolution, and climate change impact the economic and social aspects of development and creates new challenges, more players in this field both at the state level and non-state actors (corporations, organizations, NGOs, and various organized civil groups and universities) are involved in the process of finding innovative approaches and solutions especially through the use of educational tools. Therefore, it is salient to assess the practice of mobilizing and educating youth for the implementation of the SDGs and improving their ICT literacy in general and for IR and UN studies in particular. In addition, there is a need to identify the most effective instruments for engaging with youth by utilizing digital tools and taking advantage of smart gadgets revolution for effective engagement and mobilization of young people for education - and actions - around the implementation of sustainable 
development goals and global citizenship education (Abazov, 2021a).

\section{Problem statement}

The issue of improving the effectiveness of educating in IR and UN studies, and improving youth literacy in knowledge about globalization, SDGs, and climate change has been widely discussed in academia (Gregersen-Hermans \& Lauridsen, 2021; Abazov, 2021a). As the reality of climate change and global developmental inequality in combination with the consequences of the global COVID-19 pandemic prove to be much bigger and have more negative impacts on the well-being of different groups in society in both developing and developed countries (Iivari, Sharma, \& Ventä-Olkkonen, 2020), there is a need for better understanding of tools for social innovations and mobilization of youth and their more active involvement in dealing with the challenges of implementing SDGs. In this context, this paper studies three aspects digital transformation in education as follows: a) the current trends in adapting digital tools for improving teaching and training skills and competencies to be more effective in modern globalized "flat world"; b) the impact of digital transformation on improving practical skills and competencies, involving youth in practical training and extracurricular activities in IR and UN studies; and c) the changing role of the Model UN as an offline and online digital supplementary learning platform for IR and UN studies. Altogether, addressing these issues can us help to better understand existing problems and to find more effective tools for further digital transformation in the future.

\section{Literature review}

This section provides a concise overview of the literature on digital transformation in higher education, covering recent publications on the impact of digital transformation on education with a focus on IR and UN studies. The goal of this literature review is twofold. One purpose is to explore recent changes in educational approaches in IR and UN studies and the increasing impact of digital transformation of education on the dynamics of youth engagement in offline and online education. Meanwhile, the second is to assess how globalization (Friedman, 2007) and these changes in the digitalization of the educational environment affect youth activism to mobilize youth to achieve desirable public engagement and "connectivity." By assessing the impact of new digital trends on the offline educational environment as well as on online extracurricular activities, this article will make a stimulating contribution to the growing body of literature on the shift in relations between universities and student youth who are increasingly organizing themselves in their own world of "social networking and online socialization" (van Dijck, 2013).

For the purpose of this research, we can synthesize a broader definition of digital transformation reflecting major publications and views, as follows: Digital transformation in education is the process of adoption of various digital technologies by organizations, including the use of ICT, social media, mobile devices and gadgets, and data analytics, to address specific goals and objectives.

In recent studies of digital transformation, many scholars have dedicated their research to the impact of digital transformation on everyday life and economic and social development. One important aspect of the current changes is the impact of digital transformation on organizational culture (Trushkina et al., 2020; Dementyev et al., 2021) and "the human element of digital transformation (agility, P2P collaboration, lifelong learning (LLL), ICT empowerment, communication and skills mobility, etc.) that influences successful organizational culture development" (Trushkina et al., 2020: 30). However, in order to better understand the digital transformation some scholars argue that digital transformation should be deconstructed into "three categories, namely technology readiness (e.g. ICT investments), digital technology exploration (e.g. research and development), and digital technology exploitation (e.g. patents and trademarks)" (Jafari-Sadeghi et al., 2021: 100).

Indeed, digital transformation affects many aspects of our lives, including education in general and higher education in particular. Digital transformation not only improves the effectiveness of the educational process but also changes the entire paradigm in HEIs. Mohamed Hashim and colleagues (Hashim, Mohamed, 2021: 3) argue that we are seeing a paradigm shift in strategic management of HEIs as "digital transformation in the global education industry validates the future roadmap to sustainable education management." Some scholars take a step further, arguing that the digital transformation helps to equip student youth for the needs of the fourth industrial revolution by providing them with "cognitive, social, interpersonal, [and] technical skills" and "builds new skills and models through digital technologies in a deep and strategic way" (Katyeudo \& Souza, 2021: 1).

Recent studies (Lacka et al., 2021; Santos et al., 2019) suggest that students' use of communication technologies and social media 
is among the most important and visible parts of the digital transformation in the higher education process, proving "useful to increase the level of communication between students and teachers in higher education arena" (Santos et al., 2019: 124). This can be achieved by "taking advantage of the greater accessibility afforded by CT [communication technologies]" (Santos et al., 2019: 124).

In the context of studies of digital transformation of IR and UN studies, with a focus on the Model UN as a supplementary learning platform for IR and UN studies, we can argue that the digital transformation has supported students and educators in facilitating "connectivity", more efficient use of ICT technologies and mobile smartphones networking. For example, Brett Levy claims that "Model UN clubs as a scaffolded youth-adult partnership and [providing] three major types of support: intellectual, administrative, and personal" (Levy, 2016: 13), while Sharon Jones in her research on the role of Model UN in learning and youth engagement suggests it is an effective tool in interacting with students and provides "a large learning curve" (Jones, 2010: 3).

In this regard, recent studies on the impact of the COVID-19 pandemic on the entire higher education process, and on interactions with and between students, suggest that the digital transformation has been playing an especially prominent role. It has been critical in helping to transform learning practice and information management according to current needs and the current situation in educational environments (Iivari, Sharma, \& Ventä-Olkkonen, 2020).

In the context of the Silk Way region, the digital transformation has brought many positive changes (though spread very unevenly) in the field of higher education, opening new opportunities and perspectives for improving the effectiveness of educational processes and extracurricular activities. For example, some universities in the region began intensively implementing the digital transformation a decade or two ago, thereby transforming many aspects of education. One of the most important aspects of digitalization has been improving the effectiveness of information management, information resources, and access to the data bases of research studies, making them easier to use for educational purposes. The study of the digital transformation of education in general and teaching IR and UN studies in particular suggests that the digital transformation in education optimizes access to international documents, materials, and publications as well as to video materials from archives or live transmission. For example, the digital transformation of Model UN has been instrumental in changing it into a kind of an offline and online digital supplementary learning and communication platform for IR and UN studies and in upscaling these platforms in terms of greater outreach and often integrating them into a formal educational process.

\section{Educational context}

In Kazakhstan as in many countries in Central Asia, a key aspect of changes in higher education over the past two decades was the internationalization of the entire educational process involving faculty members and students in various international educational and research programs and exchanges to gain practical experience with various international entities and through changing curricula, participation in a range of curricular activities, hands-on trainings for educators and students, and internship programs including those offered by international organizations, diplomatic missions, and foreign universities. Significant changes came about in the early 2000s with the introduction of the Bologna Process and three-level education: bachelor, masters, and $\mathrm{PhD}$. Universities regularly updated their educational programs according to changing demand from the labor market (Abazov, 2021b), taking into consideration professional requirements and technological changes.

A significant feature of the internationalization of the educational process has been the introduction and development of new educational programs and revising curriculum including initiating subjects in IR and UN studies which have been relatively recently, in the 1990s. A systematic approach to teaching these subjects began in the late 1990s and underwent significant changes in the context of reforming higher education and internationalization. In this context, universities in Almaty and other cities around the country have been establishing close relations with the UN agencies in Kazakhstan, facilitated by the United Nations Information Office (UNIC, currently United Nations Global Communication Department) and organizing a series of regular meetings and presentations about UN activities in Kazakhstan and in the region, involving local and international staff members. The universities with support from the UNIC have frequently organized in-class roundtables and discussions on global issues, lately on the Millennium Development Goals (MDGs), SDGs, SOP26, and UN Agenda 2030. The collaboration between universities in Kazakhstan and UN agencies was particularly strengthened and took on a more systematic structure with the establishment of the 
UN Regional Resource Center at Al-Farabi KazNU in 2012 and establishing United National Academic Impact (UNAI) Program at Al Farabi KazNU. ${ }^{1}$ The Center has coordinated various activities with the $\mathrm{UN}$ agencies, other international organizations, and foreign embassies/consulates. It serves as a standalone educational center for facilitating engagement and various research and practical activities in IR and UN studies (Kuzhabekova, A., \& Lee, Jack T., 2020). The UNAI promoted many UN-supported initiatives including various volunteer programs, training sessions, and international conferences at al Farabi KazNU and many universities around the country. Around the same time, students from the International Relations Faculty at KazNU also organized the first Model UN club and smallscale debates on global and regional issues for undergraduate students.

The involvement and mobilization of youth in Model UN clubs has become an innovative step in upscaling youth engagement in IR and UN studies and reaching out to students in other HEIs in Almaty and all major cities in Kazakhstan, particularly those interested in Model UN activities and IR and UN studies. ${ }^{2}$ During the first stage, Model UN clubs functioned at several universities in Almaty City, attracting students and youth activists exclusively through offline direct communication channels. The first large-scale regional Model UN club emerged as the Model UN New Silk Way program (MUN NSW) in 2013 in the format of a youth debate club anchored at Al Farabi KazNU. It is important to highlight that the MUN NSW appeared and progressed in close cooperation with the UN Information Center in Almaty, ${ }^{3}$ and with the support of the diplomatic community in Almaty, especially the Consulate General of the USA. ${ }^{4}$ Gradually, the format of interaction between the MUN NSW and universities has changed as MUN NSW in coordination with UNAI and other partners has become a reginal hub for non-formal IR and UN studies and activities.

\footnotetext{
${ }^{1}$ For UN Regional Resource Center at the Faculty of International Relations Al-Farabi KazNU, please see info about some activities: https://www.kaznu.kz/RU/17055/adverts/2269

For United Nations Academic Impact (UNAI) Program at Al-Farabi KazNU, please see: http://unaihub.kaznu.kz/?lang=en

${ }^{2}$ It is important to highlight that the first Model UN clubs emerged in the early 2000s in the format of youth debate clubs at Al Farabi Kazakh National University and some other HEIs in Almaty and all major cities in Kazakhstan.

3 Please see for additional info: https://unic.un.org/ directoryweb/Office.aspx?id=4 (accessed on October 21, 2021).

${ }^{4}$ Please see for additional info: https://kz.usembassy.gov/ almaty-kazakhstan-kazakh-national-university-may-1-3-2014/ (accessed on October 21, 2021).
}

Such interaction and youth involvement have especially grown since 2015 with the introduction of 17 SDGs and the implementation process for those goals at the local and national level.

As a next step, the digital transformation of higher education (development of ICTs, social media, and digital transformation) was often used - among other things - as a tool for the internationalization of education. In the case of the MUN NSW, the opportunities provided by digital transformation were systematically and innovatively used contributing to upscaling and digitalizing the interactions between students within and between universities. ${ }^{5}$ Between 2013 and 2019, the MUN NSW regularly reached university and college students from many universities not only in Kazakhstan but also in Central and South Asia (including Afghanistan) especially for its flagship International MUN NSW Conference.

During the past decade, Model UN movement has emerged as a combination of student-led debate clubs and extracurricular educational, communication and socialization platforms bridging the formal IR and UN studies with the non-formal trainings, practical exercises, strengthening public engagement skills and competencies, and other activities of students involved in promoting, popularizing and implementing UN-led and various initiates in implementing SDGs, fighting climate changes and localizing many environmentally oriented actions.

Methods of data collection

The materials for this article were collected as part of research on the internationalization of education using the example of Kazakhstan, and work on a conference paper on United Nations Academic Impact (Abazov, 2021b). Special attention was given to the selection of qualitative materials that would illustrate the digital transformation. In working on the article, the author analyzed the set of materials as follows:

Identified a set of primary published and unpublished documents (publications of annual Model UN New Silk Way Annual Reports, UNAI Annual Reports, MDP Annual Reports and some others, completed between 2012 and 2020).

Collected unpublished articles and news reports (including traditional and new social media publications, etc.) for content analysis.

Conducted a series of qualitative interviews with students and activists of Model UN clubs,

${ }^{5}$ The Model UN New Silk Way program was developed with the support of a series of grants from the Consulate General of the USA in Almaty, Kazakhstan. 
including the Model UN New Silk Way Organizing Committee.

Completed a series of qualitative interviews with teachers and mentors from several faculties from Al Farabi KazNU and other universities.

Summarized the results of direct and indirect observations of Model UN New Silk Way activities.

Data analysis: Case study of youth engagement in Model UN

This study analyzes the impact of digital transformation on teaching practices in IR and UN studies, using the example of the MUN NSW. The researcher used qualitative and some quantitative data collected for the study. The collected materials were grouped into three sections utilizing the theoretical research model suggested by JafariSadeghi et al. (Vahid Jafari-Sadeghi, et al, 2021) and focusing on three stages:

Technology readiness.

Digital technology exploration.

Digital technology exploitation.

Jafari-Sadeghi and colleagues (2021) argued that this approach helps us to deconstruct the process of digital transformation into clearly defined stages and offers a more systematic approach in analyzing digital transformation in higher education.

\section{Technology readiness}

Technology readiness in many developing countries is often initiated from two sides: a top-tobottom process often initiated by governments, and a bottom-up process usually initiated by universities. In this regard, Kazakhstan introduced several initiatives in developing and implementing the State Program "Digital Kazakhstan" digitalization in many sectors of economy, social, public policy sectors and education. For example, Kazakhstan reached $29^{\text {th }}$ position in the UNDESA global e-governance ranking in 2020, up from $46^{\text {th }}$ place in 2010 and $81^{\text {st }}$ in $2008 .{ }^{7}$ Kazakhstan had 120 Mobile cellular telephone subscriptions per 100 inhabitants (for comparison - 52.8 in 2008), 78.9 Percentage of individuals using the Internet in 2020 (for comparison $-8.42 \%$ in 2008), and 77.57 active mobile broad-band subscriptions per 100 inhabitants (for comparison $0.21 \%$ in 2008) (UNDESA, 2020, 2021).

In the case of $\mathrm{Al}$ Farabi KazNU, it was the university that was an initiator of digital transformation through its "Strategy for

\footnotetext{
${ }^{6}$ For additional information, please see: https://www.primeminister.kz/en/news/16155 (accessed on November 29, 2021)

${ }^{7}$ For comparative data please see: https://publicadministration.un.org/egovkb/en-us/Data/Country-Information/id/87-Kazakhstan (accessed on November 29, 2021)
}

Development of Al Farabi KazNU (2012-2017)" (Al-Farabi KazNU, 2012). This involved a large and ambitious program for developing digital readiness through investing in hardware in the form of ICT equipment, creating computer labs, setting up internet infrastructure, and acquiring software to enable the entire process of digital readiness.

At the same time, there was an ongoing process of "digitalization" of students and faculty members, as they began using smartphones and other gadgets to integrate themselves into global cyberspace, in the process called "developing connectivity" (van Dijck, 2013).

At the beginning these two processes - the digitalization of the university and digitalization of youth communities - remained in two separate universes. The university focused on creating a ecosystem of hardware and continued to prepare and adapt it for university needs, including increasing the effectiveness of ICT equipment usage among faculty members and $\mathrm{PhD}$ researchers. At the same time, the student youth actively used their gadgets in developing their "digital readiness" to access the global cyberspace, experimenting with social media and building communities of like-minded people, for coordination of their activities (usually extracurricular) and for other non-educational needs.

In the case of IR and UN studies, this "technology readiness" contributed to the development of internationalization programs and educational process by helping to build up "connectivity" with various external partners for offline activities. This included promoting students activism and youth engagement through Model UN activities.

\section{Digital technology exploration}

The second stage of digital transformation involves experimenting with and exploring the new hardware and software, new technologies, and new applications for adaptation to the educational process. This is a complicated process that not only requires integration of digital technologies into the existing standards and formats of education, but also requires experimenting with the new technologies for localization of these digital opportunities for the local needs and local organizational culture of the education process (El Massah \& Mohieldin, 2020). Among other things, the human factor in the exploration of new digital technologies is especially important for optimizing the digital transformation for the specific needs and requirements of a classroom. With this in mind, life-long learning including training, training of trainers, workshops, and seminars - could become an important tool for winning the hearts and minds of faculty members, 
education managers, and students to be open to innovations and new technologies (Merrill, M., Yakubova, S., \& Turlanbekova, Z., 2021). Promoting best practices and examples of digital transformation adapted for specific educational needs can also contribute to success.

In the context of digital transformation in teaching IR and UN studies, experimentation with new technologies has practical applications. In the format of the extracurricular activities of MUN during the process of implementation, MUN NSW had been focusing on key practical aspects of educational and youth mobilization process including regular monthly training on MUN procedures and brainstorming on organizational issues and use of ICT, including the use of mobile devices and social media. The analysis of interviews and annual reports of MUN NSW illustrates that this experimentation was conducted at several levels with different degrees of success as follows:

The popularization of Model UN, including MUN NSW;

Mobilization of use for greater participation and recruitment of new members for Model UN;

Popularization of global agenda of themes for Model UN including SDG is, SOP26 and action against climate;

Digital public relations campaign, in and outside of class, for promoting international global agenda through Model UN activities.

Many universities across the region (like Al Farabi KazNU), have begun using the digital transformation opportunities in order to access to digital hardware and ICT, to build up the more effective knowledge management, implementation of communication strategies, and delivery and visualization of information and research materials in organizing jointly with various local and international partners to provide offline and online national and international seminars, workshops, and conferences in IR and UN studies including promoting non-formal trainings and education through Model UN activities.

Box 1

Model UN has been particularly successful in establishing one of the most productive relations between higher education institutions and $\mathrm{UN}$ agencies not only in Kazakhstan but also in Central and South Asia...

Interview with an IR student in 2018

\section{Digital technology exploitation}

The third stage of digital transformation is a stage of digital technology exploitation which offers both faculty members and students the opportunity to actively use digital tools in the educational process overall, and in organizing extracurricular activities and practical trainings in particular. In our case, this includes the usage of innovation approaches in the delivery of IR and UN studies. The active usage of ICT contributed to widening students' access to international online training materials, documents and publications, and to online interactions of students inside and between HEIs, and more efficient use of mobile devices and social media communication opportunities in learning and practical training process.

According to the interviews, students and faculty members significantly increased their use of digital technologies - including both hardware/software accumulated by universities and gadgets acquired by students for personal use. This is particularly visible in the use of ICT in communication for education and organizing lifelong learning through online international conferences, training workshops, and roundtables. In the context of the work of MUN, digital transformation radically changed the entire process of interaction between activists, Model UN clubs, and UN agencies (Shaw, Carolyn M., 2020). In addition, ICTs contributed to greater interactions between students within Central Asia (Kazakhstan, Kyrgyzstan, Tajikistan, Turkmenistan, and Uzbekistan), as MUN NSW established and actively used a network of social media outlets (such as Facebook, Instagram, Twitter and VKontakte) reaching out up between 2,000 and 5,000 young people per week. They also contributed to inaugurating and developing online interactions of students from five Central Asian republics with students from Afghanistan.

Digital exploitation received an additional strong boost in 2020 and 2021 due to the restrictions and closures of public entities (including universities) related to the COVID-19 pandemic (Iivari, Netta, Sharma, Sumita, \& Ventä-Olkkonen, Leena, 2020).

Indeed, the analyzed evidence and data suggest that at this stage, the usage of digital technologies has become more systematic and regular at all levels of the educational process, and in changing the role of Model UN from an offline discussion club into an offline and online digital supplementary learning platform for IR and UN studies.

Box 2

[Digital transformation and] social media completely transformed Model UN New Silk Way's outreach and the scale of engagements with students in the Great Silk Way region...

Interview with a Model UN activist in 2021 


\section{Conclusion and discussion}

This section summarizes the findings of the research and thoughts about the impact of digital transformation on IR and UN studies using the example of the MUN NSW program. Such analysis is particularly necessary as assessment of the impact of digital transformation on HEIs in general as well as specific subject studies suggests that this process is very complex.

Digital transformation has contributed to the development of digitalized learning and communication processes and the application of new technologies through expanding a variety of training and communication platforms for educational purposes. The advancement of digital skills among students and other stakeholders combined with widespread Internet access has become a major force in the digital transformation of education including IR and UN studies.

The methodological approach used in the study suggested the value of deconstructing the digital transformation into three major steps (technological readiness, technological exploration, and technological exploitation) in order to identify the stages of digital transformation and its impact on the learning process. In essence, the approach suggested a structured analytical framework for understanding the impact of digital transformation acceleration over time, not only in introducing digital technologies into education but also the ways in which digital transformation changes the work and efficiency of the educational process.

A series of interviews (qualitative surveys) conducted with major stakeholders of the MUN NSW program indicated that digital transformation is not a linear process and includes a series of very important steps in developing digital readiness. True, all major stakeholders eventually received access to digital technologies and mastered them for everyday use. However, digital readiness in HIEs (and consequently in Model UN) could be successful only if appropriate work is done with the human development aspects (Harper \& Dunkerly, 2009). Thus, the interviews suggested that MUN NSW participants have used the digital capacity building process (both among students and educators) to develop skills and competencies in dealing with digital opportunities in the context of cohesive and workable educational eco-systems (educational platforms) and increasing mobilization of youth for MUN NSW and other volunteer activities.

This research also highlighted the importance of the second step: digital technology exploration. It is not enough to acquire the infrastructure, put it in place, and make it workable. It is an equally important part of the process to explore ways to use all those technologies (ICT networks, Internet infrastructure, social media, apps, and communication tools) for educational, training, and mobilization purposes. Here again, the interviews and collected data suggested that despite widespread use of digital technologies for personal use and despite having access to digital infrastructure, young people do not automatically convert access to technologies into effective use of digital technologies for educational purposes. Indeed, Model UN stakeholders required time to explore the digital opportunities and the new possibilities for effective use in the educational process. There can be many barriers and challenges in the effective management of digital exploration. For instance, there was no effective and systematic learning process about the opportunities provided by digital technologies, which would include not only general knowledge about the technology aspects of digital transformation but also the little-recognized soft components, such as organization of learning about digital trends, embracing organizational culture, and lack of training and educational counselling services support.

In addition, the research suggests that digital exploitation is the most essential part of digital transformation, as digital readiness and exploration alone do not guarantee the effective exportation of digital infrastructure for educational purposes and for IR and UN studies. The case of the Model UN New Silk Way at al-Farabi KAZNU - which probably reflects the situation in Kazakhstan and many developing countries - suggests that digital exploitation may contribute to improving IR and UN studies by upscaling Model UN programs into digital supplementary learning platforms, focusing on their contributions to improving the learning and training process, awareness raising about SDGs, better communication and "connectivity", and increasing overall knowledge about globalization issues.

The digital transformation of MUN (through the use of ICT, apps, and social media) has changed the entire training, recruitment, implementation process, and outreach approach through greater utilization of digital technologies in recruiting and mobilizing youth. The systematic approach in using digital technologies including ICT and social media increased the effectiveness of youth mobilization and transformed the Model UN into an effective offline and online digital supplementary learning platform for IR and UN studies.

In sum, the further digital transformation of IR and UN studies, including Model UN programs, 
requires a comprehensive and structured approach in managing hard and soft components, skills and competencies. This leads to creating a learning environment that is open to innovations for effective digital transformation and mobilization - not only for educational purposes and global citizenship education, but also for mobilization of use for implementing SDGs and other action-oriented activities.

\section{References}

Al-Farabi KazNU. (2012), Strategia razvitia Kazakhskogo Natsionalnogo universiteta imeni Al Afarabi do 2020 goda. [Strategy of Development of Al-Farabi KazNU until 2020] UNAI. Almaty (Kazakhstan): Al-Farabi Kazakh National University Press, 2012.

Al-Farabi KazNU. (2014), Model UN New Silk Way Programme. Annual Report. Almaty (Kazakhstan): Al-Farabi Kazakh National University, 2014, 2015. 2016, 2018, 2019 (unpublished reports).

Al-Farabi KazNU. (2017), Strategia razvitia Kazakhskogo Natsionalnogo universiteta imeni Al Afarabi na 2017-2021 gody. [Strategy of Development of Al-Farabi KazNU 2017-2021] UNAI. Almaty (Kazakhstan): Al-Farabi Kazakh National University Press, 2017.

Al-Farabi KazNU. (2020), Al-Farabi KazNU for Shaping Common Future. Almaty (Kazakhstan): Al-Farabi Kazakh National University Press, 2020. Available at: http://unaihub.kaznu.kz/?p=2072\&lang=en (accessed on April 2, 2021).

Al-Farabi KazNU. (2021), Al-Farabi KazNU Global Hub of UNAI. Almaty (Kazakhstan): Al-Farabi Kazakh National University Press, 2019. Available at: http://unaihub.kaznu.kz/wp-content/uploads/2020/10/al-Farabi-KazNU-Global-Hub-of-UNAI.pdf (accessed on May 2, 2021).

Abazov, Rafis. (2021a), Redefining global citizenship education: a case study of Kazakhstan. Journal of Philosophy, Culture and Political Science (Al-Farabi Kazakh National University), [S.1.], Volume 75, n. 1, 2021, pp. 90-99. Available at: https://bulletinphilospolit.kaznu.kz/index.php/1-pol/article/view/1235 (accessed on May 2, 2021).

Abazov, Rafis. (2021b), Engaging in the internationalization of education and SDGs: Case study on the global hub of UNAI on sustainability. E3S Web Conf., Volume 307, 2021. Available at: https://www.e3s-conferences.org/articles/e3sconf/pdf/2021/83/ e3sconf_dsdm2021_06001.pdf (accessed on October 12, 2021).

Chapman, D. W., Pekol, A., \& Wilson, E. (2014), Cross-border university networks as a development strategy: lessons from three university networks focused on emerging pandemic threats. International Review of Education, Volume 60, 2014, pp. 619-637.

Cheng, Angel Oi Yee. (2019), Global Mission - "Glocal” Internationalization: United Nations Academic Impact (UNAI) and Lehigh University. Journal of Comparative \& International Higher Education, Volume 11, Spring, 2019. Available at: https://www. ojed.org/index.php/jcihe/article/view/929 (accessed on October 21, 2021).

Dementyev, V., Dalevska, N., \& Kwilinski, A. (2021). Innovation and Information Aspects of the Structural Organization of the World Political and Economic Space. Virtual Economics, Volume 4, No 1, pp. 54-76. Available at: https://virtual-economics.eu/ index.php/VE/article/view/103 (accessed on October 21, 2021).

El Massah, Suzanna, \& Mohieldin, Mahmoud. (2020), Digital transformation and localizing the Sustainable Development Goals (SDGs), Ecological Economics, Volume 169, 2020. Available at: https://www.sciencedirect.com/science/article/pii/ S0921800919303258 (accessed on October 21, 2021).

Friedman, Thomas L. (2007). The World Is Flat: The Globalized World in the Twenty-First Century. New York: Penguin, 2007

Gregersen-Hermans, Jeanine, \& Lauridsen, Karen M. (eds). (2021), Internationalising Programmes in Higher Education: An Educational Development Perspective (Internationalization in Higher Education Series) 1st Edition. New York: Routledge, 2021.

Harper, Helen, \& Dunkerly, Judith. (2009), Educating the world: Teachers and their work as defined by the United Nations Educational, Scientific and Cultural Organization (UNESCO). Current Issues in Comparative Education, Volume 12, n. 1, 2009, pp. 56-65.

Hashim, Mohamed Ashmel Mohamed, Tlemsani, Issam, \& Matthews, Robin. (2021), Higher education strategy in digital transformation. Education and Information Technologies. Available at: https://ink.springer.com/article/10.1007\%2Fs10639-021-10739-1 (accessed on October 21, 2021).

Hudzik, John K. (2014), Comprehensive Internationalization: Institutional Pathways to Success (Internationalization in Higher Education Series) 1st Edition. New York: Routledge, 2014.

Iivari, Netta, Sharma, Sumita, \& Ventä-Olkkonen, Leena. (2020), Digital transformation of everyday life - How COVID-19 pandemic transformed the basic education of the young generation and why information management research should care? International Journal of Information Management. Volume 55, 2020.

Jafari-Sadeghi, Vahid, Garcia-Perez, Alexis, Candelo, Elena, \& Couturier, Jerome. (2021), Exploring the impact of digital transformation on technology entrepreneurship and technological market expansion: The role of technology readiness, exploration and exploitation, Journal of Business Research, Volume 124, 2021, pp. 100-111. Available at: https://www.sciencedirect.com/science/ article/pii/S0148296320307736 (accessed on October 11, 2021).

Jones, Sharon. (2010), Model UN and class roles: case studies in role playing and simulations for learning and engagement. The 2010 APSA Teaching \& Learning Conference. February 5-7, 2010. Available at: https://papers.ssrn.com/sol3/papers.cfm?abstract_ id $=1546091$ (accessed on October 11, 2021).

Kuzhabekova, A., \& Lee, Jack T. (2020), Internationalization and local research capacity strengthening: Factors affecting knowledge sharing between international and local faculty in Kazakhstan. European Education, Volume 52, n. 4, 2020, pp. $297-311$. 
Lacka, Ewelina, Wong, T. C., \& Haddoud, Mohamed Yacine. (2021), Can digital technologies improve students' efficiency? Exploring the role of virtual learning environment and social media use in higher education. Computers \& Education, Volume 163, 2021, Available at: https://www.sciencedirect.com/science/article/pii/S0360131520302979 (accessed on October 11, 2021).

Levy, Brett L. M. (2016), Advising a Model United Nations club: A scaffolded youth-adult partnership to foster active participation and political engagement. Teaching and Teacher Education, Volume 59, 2016, pp. 13-27. Available at: https://www.sciencedirect.com/science/article/pii/S0742051X16300555 (accessed on October 21, 2021).

Merrill, M., Yakubova, S., \& Turlanbekova, Z. (2021), Internationalizing quality assessment in Central Asia. International Higher Education, n. 64, March 2011. Available at: https://ejournals.bc.edu/index.php/ihe/article/view/8561 (accessed on May 20, 2021).

Oliveira, Katyeudo K. de S., \& de Souza, Ricardo A. C. (2021), Digital transformation towards education 4.0. Informatics in Education, forthcoming.

Santos, Helena, Batista, João, \& Marques, Rui Pedro. (2019), Digital transformation of higher education: The use of communication technologies by students. ScienceDirect. Procedia Computer Science. Volume 164, 2019, pp. 123-130.

Shaw, Carolyn M. (2020), The Unexpected Gift: "Oh, and you'll be responsible for the Model UN program." In: Pedagogical Journeys through World Politics (Ed. Jamie Frueh). New York: Palgrave, 2020. Available at: https://link.springer.com/ book/10.1007/978-3-030-20305-4 (accessed on October 21, 2021).

Trushkina, Nataliia, Abazov, Rafis, Rynkevych, Natalia, \& Bakhautdinova, Guzelya. (2020), Digital transformation of organizational culture under conditions of the information economy. Virtual Economics, Volume 3, n. 1, 2020, pp. 3-32.

UNAI. (2020), About UNAI. n.d. Available at: https://www.un.org/en/academic-impact/page/about-unai (accessed on May 2, 2021).

UNAI. (2011), The United Nations Academic Impact Is Informed by a Commitment to Support and Advance Ten Basic Principles (2011). Available at: http://unaihub.kaznu.kz/?page_id=15\&lang=en (accessed on May 2, 2021).

UNDESA (2020), 2020 United Nations E-Government Survey. New York: UNDESA, 2020. Available at: https://publicadministration.un.org/egovkb/Portals/egovkb/Documents/un/2020-Survey/2020\%20UN\%20E-Government\%20Survey\%20(Full\%20 Report).pdf (accessed on December 2, 2021).

UNDESA (2021), Kazakhstan: e-governance data. Available at: https://publicadministration.un.org/egovkb/en-us/Data/Country-Information/id/87-Kazakhstan (accessed on December 2, 2021). 2013.

Van Dijck, José. (2013), The Culture of Connectivity: A Critical History of Social Media. Oxford, UK: Oxford University Press,

Zain, Sayeda. (2021), Digital transformation trends in education. In: Chandos Digital Information Review, Future Directions in Digital Information (ed. David Baker, Lucy Ellis). Chandos Publishing, 2021, pp. 223-234. Available at: https://www.sciencedirect. com/science/article/pii/B9780128221440000367 (accessed on October 21, 2021).

\section{Acknowledgements and research note}

This article is a part of a larger study undertaken on the internationalization of higher education and education for sustainable development. The full-scale research on this topic was envisioned to be conducted throughout the year 2020. Initially it included a series of focus groups, semi-structured interviews, and questionnaire-based survey study.

However, due to the COVID-19-related lockdowns and restrictions, the initial plans were adjusted and the research was divided into a series of mini studies completed in 2020 and 2021. The first study covered the introduction of ESD, using the example of the MDP program at al-Farabi KazNU. The second study covered the introduction of global citizenship education at the university level. The third study was envisioned to cover the impact of global institutions and initiatives, such as UNAI, on the internationalization of higher education and the introduction of ESD.

Some ideas from this research were presented at the "Fifth North and Central Asia Multi-Stakeholder Forum on Implementation of the Sustainable Development Goals. Building Back Better from COVID-19 while Advancing the Full Implementation of the 2030 Agenda for Sustainable Development," presented in virtual meeting format, 5-7 October 2021.

Thank you note: The author would like to express his gratitude to his colleagues for their support, encouragement, and comments on an early draft of this paper as follows: Mukhametkali Burkitbayev, Leila Delavarova, Galiya Ibraeva, Gulshat Minazheva, Vlastimil Samek, Tursunkul Bazarbayeva, Bibinaz Almanova, Maiya Suyunchaliyeva, Zhansaya Isayeva, Anastasia Fedorova, and many other colleagues. 